\title{
Mudanças no uso da terra em microbacias hidrográficas urbanas e impactos sobre as águas pluviais e os solos: o caso da microbacia do córrego Água da Veada, Ourinhos-SP ${ }^{1}$
}

Land use changes in urban watersheds and impacts on rainwater and soils: the case of Água da Veada microbasin, Ourinhos-SP

\author{
Edson Luís Piroli ${ }^{A}$ \\ LeONARDo Auge LeVYMan ${ }^{B}$
}
${ }^{a}$ Professor e pesquisador na Universidade Estadual Paulista (Unesp), campus de Ourinhos, livre docente em Sensoriamento Remoto e Geoprocessamento pela Unesp.
E-mail: edson.piroli@unesp.br

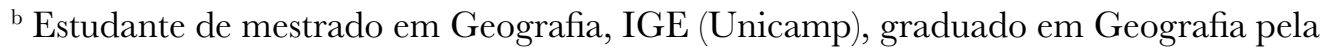
Universidade Estadual Paulista (Unesp), campus de Ourinhos.
E-mail: leoauge@hotmail.com

\begin{abstract}
A ação antrópica promove mudanças no uso da terra e alterações no ciclo hidrológico, resultando na redução das taxas de infiltração e no aumento do escoamento superficial. Como consequência, aumentam os episódios de inundação e as taxas de erosão e de assoreamento. O município de Ourinhos-SP, fundado no início do século XX, sofreu considerável alteração na cobertura vegetal de seu território ao longo de sua história, de forma que a floresta estacional semidecidual foi gradualmente substituída por culturas agrícolas, pela pecuária e pela área urbana. Esta última se ampliou consideravelmente nas últimas décadas, trazendo consigo intensos processos de impermeabilização, o que reduziu as taxas de infiltração das águas das chuvas e aumentou o escoamento superficial, as enxurradas e suas consequências. Nesse contexto, o objetivo desta pesquisa é analisar a relação entre as transformações no uso da terra ocorridas nas últimas décadas na microbacia hidrográfica do córrego Água da Veada (MCAV) e os processos erosivos e de assoreamento delas resultantes entre os anos de 1972 e 2016. Os resultados demonstram que a microbacia teve aumento considerável na ocupação urbana, nos processos de escoamento superficial nas erosões e nos assoreamentos do leito do córrego.
\end{abstract}

Palavras-chave: geoprocessamento, sensoriamento remoto, recursos hídricos.

The appropriation of space by humanity promotes changes in land use and changes in the hydrological cycle resulting in reduced infiltration rates and increased surface runoff. As a result, flooding episodes and erosion and siltation rates increase. The municipality of Ourinhos-SP, founded in the early 20th century, has undergone considerable change in the vegetation cover of its territory throughout its history. The Semideciduous Seasonal Forest was gradually replaced by crops, livestock, and the urban area. The latter has expanded considerably in recent decades, bringing with it intense waterproofing processes, which have reduced the infiltration rates of rainwater, increased surface runoff, runoff, and its consequences. In this context, the objective of this research was to analyze the relationship between the changes in land use that have taken place in recent decades in the Córrego Água da Veada (MCAV) hydrographic micro basin, the erosion and silting processes that resulted between 1972 and 2016. results show that the micro basin had a considerable increase in urban occupation, in the processes of surface runoff in erosion, and in the silting of the stream bed.

Keywords: geoprocessing, remote sensing, water resources.

1 Parte dos resultados obtidos com o Projeto Regular Processo Fapesp 2017/14979-0, coordenado pelo primeiro autor, do qual o segundo autor foi bolsista de treinamento técnico III. 


\section{INTRODUÇÃO}

Esta pesquisa trata essencialmente de mudanças antrópicas no uso da terra e de seus reflexos sobre o solo e a água na área da microbacia hidrográfica do córrego Água da Veada (MCAV). Pivetta (2019) indica que:

\begin{abstract}
A ação do homem se dá fundamentalmente por meio de atividades agropecuárias, uso do solo urbano e preservação de áreas naturais. Ao optar, por exemplo, por converter uma área de floresta nativa - que estocou uma quantidade considerável de carbono em sua biomassa - em pastagem para criação animal, promove-se uma grande emissão de gases de efeito estufa. As escolhas feitas pelo homem podem minimizar ou exacerbar as mudanças climáticas, que, por sua vez, levam a sociedade a novas decisões sobre como utilizar o solo, em um processo que se realimenta.
\end{abstract}

Analisando a afirmação, é possível vinculá-la ao fato de que a conversão de determinada área de floresta nativa para atividades produtivas, ou para espaços de residências e outras estruturas antrópicas, não interfere somente na liberação de carbono, mas também de água, uma vez que cada ser vivo que habita uma floresta, seja vegetal seja animal, pode ser considerado um reservatório individual de água. Assim, ao transformar a floresta em área antropizada, libera-se esse estoque de água para o ambiente em velocidade muito superior à dos ciclos naturais, geralmente transferindo-o para outros locais, como lagos e oceanos. Essa água "exportada" deixa de fazer parte do ciclo hidrológico local, interferindo nas questões de chuvas regionais, na temperatura, no mesoclima e na biodiversidade, que passa a se transformar em razão das novas condições ambientais (PIROLI, 2016).

Ao mesmo tempo, a retirada da estrutura florestal de determinada região interfere na proteção do solo, aumentando o risco de seu empobrecimento com a exportação de nutrientes, tanto pelas culturas nele implantadas quanto pelo carreamento por processos de escoamento superficial e por processos erosivos. Além disso, o uso intensivo deste, principalmente em locais com manejo inadequado, origina processos de compactação e, na sequência, de impermeabilização, fazendo com que as taxas de infiltração de água sejam reduzidas, comprometendo a recarga dos aquíferos e reduzindo as taxas de umidade do solo. Ao mesmo tempo, essa água que passa a não se infiltrar escoa superficialmente, potencializando erosões. Esse conjunto de processos influencia a perenização dos rios, a disponibilidade hídrica, a produção agropecuária e o micro e mesoclima.

Setti et al. (2000) dizem que os problemas de escassez hídrica no Brasil decorrem fundamentalmente da combinação entre o crescimento exagerado das demandas localizadas e da degradação da qualidade das águas. De acordo com os autores, esse quadro é consequência dos desordenados processos de urbanização, industrialização e expansão agrícola.

Kalnay e Cai (2003) indicaram que as maiores influências antropogênicas no clima são os gases de efeito estufa e as mudanças no uso da terra acarretadas pela urbanização e pela agricultura. Lawler et al. afirmam que mudanças no uso da terra afetam a provisão de serviços ecossistêmicos e os habitats da vida selvagem. Os autores informam que

Fornecer comida, madeira, energia, moradia e outros bens e serviços, mantendo as funções do ecossistema e a biodiversidade que sustentam seu suprimento sustentável, é um dos grandes desafios de nosso tempo. Compreender os fatores determinantes da mudança no uso da terra e como as políticas podem alterar a mudança no uso da terra será fundamental para enfrentar esse desafio. (LAWLER et al., 2014)

Partindo dessa análise, é possível verificar que as mudanças no uso da terra podem ter consequências ainda mais amplas e impactar o fornecimento de serviços ecossistêmicos, entre os quais o primeiro que se percebe é a disponibilidade e a qualidade da água. Exemplo claro disso foi a grave crise no fornecimento de água para a população urbana de algumas grandes cidades, principalmente da Região Metropolitana de São Paulo, ocorrida em 2014 e 2015. Esse problema levou inclusive a conflitos, como o ocorrido com o estado do Rio de Janeiro pelo uso das águas do rio Paraíba do Sul (OROSCO, 2018).

Jacobi, Cibim e Souza (2016) indicam que a crise hídrica ocorreu como consequência da falta de gestão, de atendimento às políticas estaduais de recursos hídricos e de saneamento e de sustentabilidade socioambiental. A partir dessas informações, considera-se que essas análises devem ser aprofundadas, inserindo as questões relacionadas ao manejo das bacias hidrográficas e das mudanças no uso da terra, uma vez que estas modificam as relações entre solo, água e vegetação, além da relação da população com esses recursos. 


\section{OBJETIVos}

Este trabalho busca levantar informações acerca das mudanças ocorridas no uso da terra da MCAV entre 1972 e 2016 e de suas consequências em termos de geração de escoamento superficial, inundações, processos erosivos e de assoreamento. Além disso, buscou-se avaliar os impactos dessas consequências sobre a população residente na área.

\section{Metodologia}

A MCAV está localizada no município de OurinhosSP, entre as coordenadas 613000 e 615000 leste, e 7460000 e 7462000 norte, do fuso 22 sul do sistema UTM (Universal Transversa de Mercator). Seu centro está localizado na coordenada $22^{\circ} 57^{\prime 2} 2^{\prime \prime}$ de Latitude Sul e 49 $53^{\prime 2}$ " de Longitude Oeste. Sua área corresponde a 258,58 hectares (figura 1).

Figura 1. Localização da MCAV no estado de São Paulo.

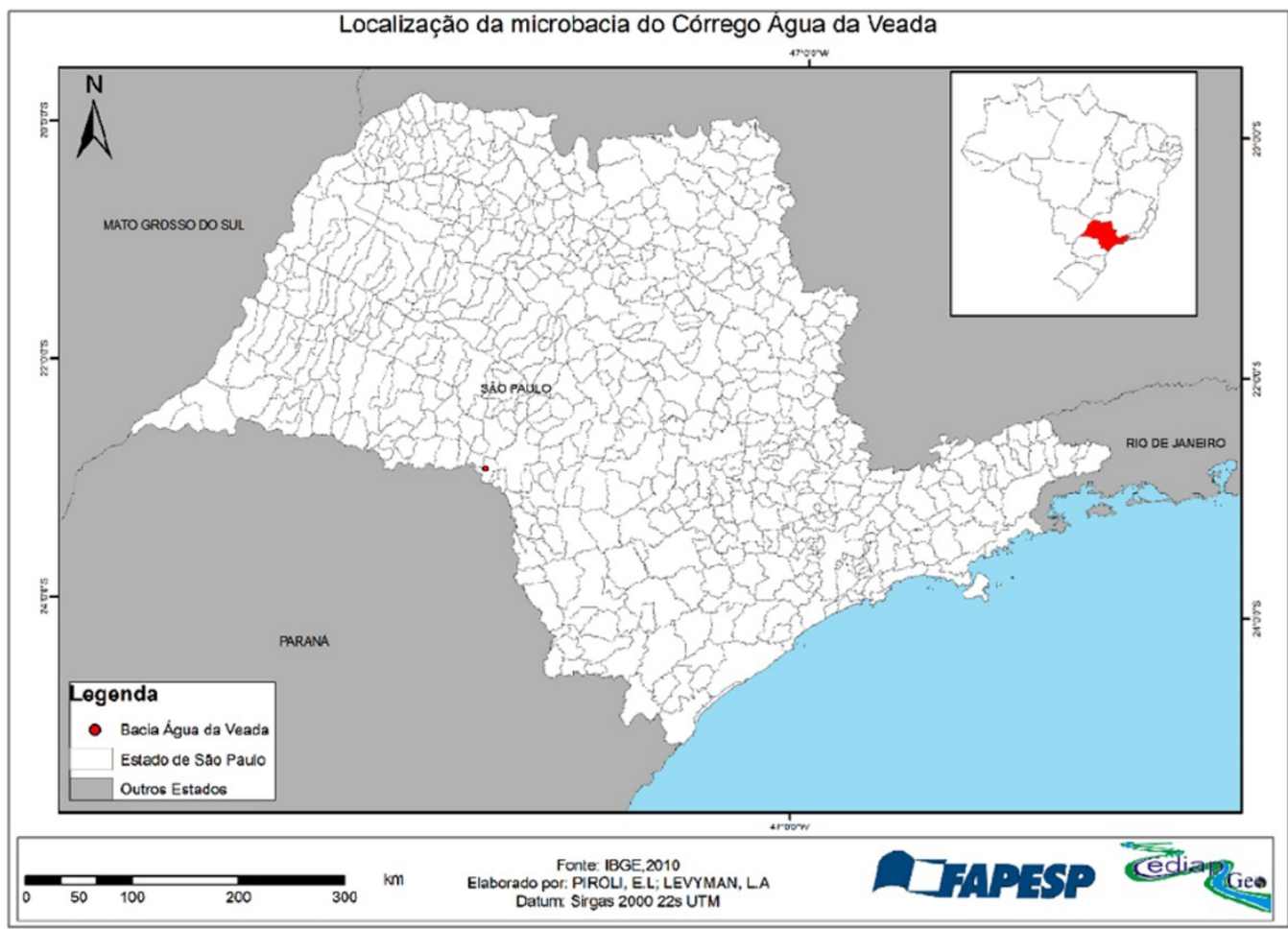

Fonte: IBGE.

Em termos hidrográficos, a área de estudo pertence à sub-bacia hidrográfica do Rio Pardo, que está localizada na região centro/sudoeste do estado de São Paulo e que integra a bacia hidrográfica do rio Paranapanema, bacia federal por abranger áreas dos estados de São Paulo e Paraná. O rio Pardo é um dos principais tributários da margem direita da bacia do rio Paranapanema e faz parte da região hidrográfica do rio Paraná, sendo um de seus mais importantes tributários da margem esquerda.

No sistema paulista de gerenciamento de recursos hídricos, a sub-bacia do rio Pardo faz parte da Unidade de Gerenciamento dos Recursos Hídricos - 17 (UGRHI-17). Os aplicativos usados neste trabalho foram os SIG (Sistemas de Informações Geográficas) ArcGIS 10.3.1 e TerrSet, e, para apoio em algumas análises e editoração, foi usado o MS Excel, o MS Access, o MS Word e o Adobe Photoshop.

A base de dados para realização do projeto foi composta pela carta topográfica de Ourinhos em escala de 1:50.000, sobre a qual foram vetorizados os corpos d'água e o limite da área de estudo. O uso da terra foi avaliado a partir de imagens dos satélites QuickBird e Geoeye extraídas do Google Earth Pro e de aerofotogramas da área de estudo, de 1972. Para serem utilizadas, todas as fontes de dados foram georreferenciadas no sistema UTM, Datum Sirgas 2000.

As análises se iniciaram com a montagem do mosaico das fotografias aéreas e das imagens dos satélites e com a georreferência delas e da carta topográfica. Em seguida, o córrego e demais corpos d'água foram vetorizados em 
uma primeira aproximação sobre a carta topográfica (na qual foram verificadas imprecisões) e, após, sobre as imagens dos satélites e dos aerofotogramas. Na etapa seguinte, elaborou-se a classificação do uso da terra da área de estudo a partir da análise visual, usando como orientação os critérios de fotointerpretação estabelecidos por Jensen (2009) e Florenzano (201 1). Em seguida, foram feitas confirmações em campo e a busca de informações relativas aos anos anteriores (1972 e 2004) em artigos, trabalhos de pesquisa, notícias de jornais e entrevistas com moradores.

Durante os trabalhos de laboratório, foram definidos locais representativos para análises aprofundadas das condições in loco. A definição desses locais foi feita em função de seu uso e da forma de ocupação, buscando-se analisar pelo menos três locais distintos para cada tipo de uso em diferentes pontos da microbacia. Os trabalhos de laboratório consistiram, então, em atividades de montagem de mosaicos, georreferência das imagens digitais, uso de operadores de distância, classificação digital e visual do uso da terra, álgebra entre mapas, criação de banco de dados, gerenciamento, entrada, manipulação e saída de dados e editoração do resultado da pesquisa.

Nos trabalhos de campo, foram anotadas as ocorrências de nascentes e mudanças no leito do córrego que não estão identificadas na carta topográfica e que não são claramente visíveis nas imagens de satélite. É válido destacar que, em vários pontos da área de estudo, houve mudanças no leito do córrego desde a época da elaboração da carta topográfica, consequência de erosões, assoreamentos e obras realizadas na área.

As categorias em que as classes de uso foram inseridas são baseadas naquelas definidas pelo Instituto Brasileiro de Geografia e Estatística (IBGE) (2013) e foram adotadas em função das características predominantes na área de estudo, onde foram classificadas com pequenos ajustes. As classes identificadas foram: solo exposto, culturas agrícolas, pastagem, rodovia, eucalipto, café, cultura agrícola anual - milho, cultura agrícola anual - soja, ravina, voçoroca, campestre, açude, área urbana, mineração e lixão.

Nas análises in loco, foram registradas em planilhas também a presença de esgoto, lixo e entulho, instabilidade das encostas e processos de drenagem e/ou aterro em função de sua influência sobre o resultado do escoamento superficial e consequente surgimento de erosões e assoreamentos.

Cada local analisado teve suas coordenadas UTM coletadas para, em seguida, serem utilizadas na elaboração do banco de dados que contém as informações georreferenciadas. Esse banco de dados foi associado às imagens de satélite e aos aerofotogramas da área de estudo, possibilitando a consulta posterior às características de cada local e atualizações futuras.

Depois da elaboração dos mapas de uso e de cobertura da terra e de sua análise quanto à acurácia, foi utilizado o módulo Land Change Modeler (LCM) do aplicativo TerrSet para a criação de mapas e tabelas com os dados sobre as mudanças que ocorreram na área de estudo nos períodos analisados. Na sequência, cada mudança no uso da terra foi avaliada quanto ao seu potencial para geração de impactos ambientais, tanto negativos quanto positivos. Ao mesmo tempo, foram feitas pesquisas na literatura especializada e entrevistas com pesquisadores, gestores públicos e moradores da região, buscando explicações sobre os motivos que levaram às transformações e suas consequências ao longo do período estudado.

Por fim, foi elaborado o modelo digital de elevação da microbacia com resolução espacial de 30 metros e os mapas de altimetria e de declividade. Esses mapas foram elaborados a partir de técnicas de interpolação nos SIG utilizando dados do sensor Aster (Advanced Spaceborne Thermal Emission and Reflection Radiometer) instalado na plataforma orbital TERRA e de dados SRTM (Shuttle Radar Topographic Mission).

\section{Resultados e Discussão}

Na avaliação feita na MCAV a partir das análises das fotografias aéreas e das imagens disponíveis no Google Earth Pro, observou-se que, à medida que as áreas urbanas se expandiam, os processos de mudança se ampliavam e modificavam, conforme pode ser visto nas figuras 2, 3 e 4, que representam a cobertura do solo em 1972, 2004 e 2016, respectivamente.

\section{Uso da terra na MCAV, Ourinhos-SP, 1972}

Em 1972 observa-se ampla cobertura da categoria pastagem na bacia, além de vegetação campestre. Havia também usos antrópicos de silvicultura, de eucalipto e uma pequena porção de área urbana adentrando a bacia. Além disso, foi possível observar a existência de ravinamentos próximos à região onde se encontra grande voçoroca atualmente, o que indica que a intensificação do uso do solo já começava a gerar consequências desde aquela época. Havia, em 1972, mais de 13 hectares de café, uso que não foi registrado nos anos posteriormente analisados. A figura 2 mostra o mapa do uso da terra da MCAV em 1972. 
Figura 2. Uso da terra na MCAV em 1972.

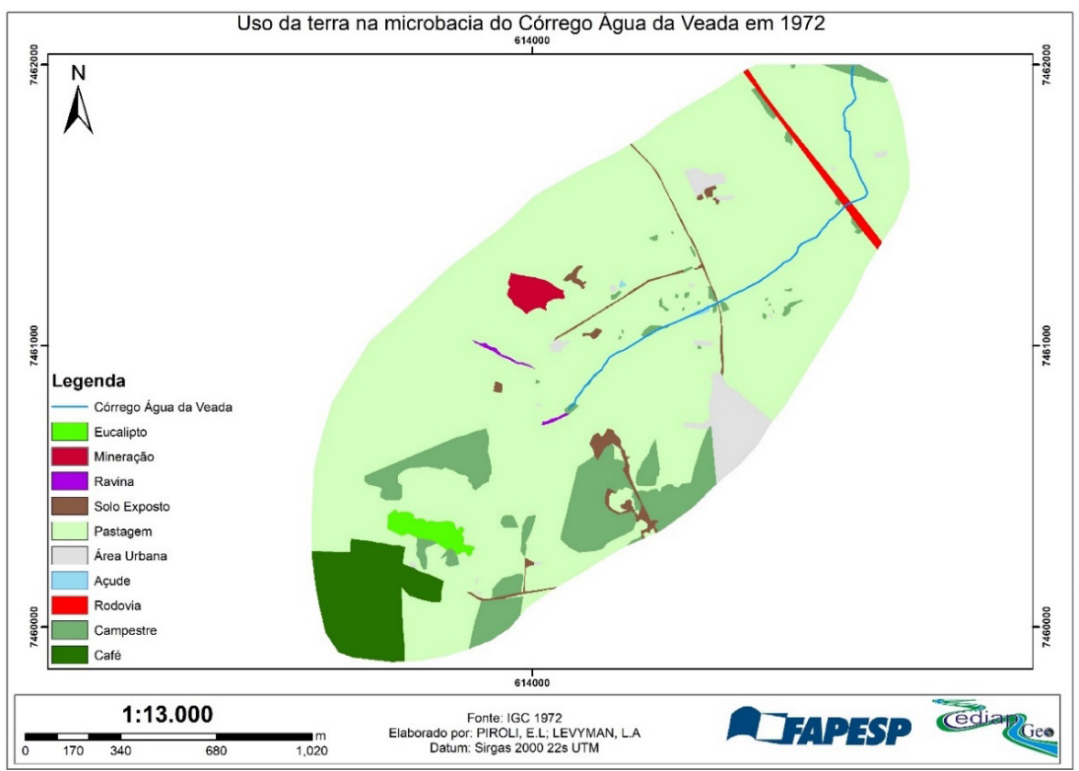

\section{Uso da terra na MCAV, Ourinhos-SP, 2004}

Em 2004 é possível verificar que importantes transformações na área. A pastagem foi reduzida para 100,94 ha, as culturas agrícolas anuais se ampliaram para 56,12 ha, a classe campestre reduziu-se para 15,49 ha e a área urbana se ampliou para 64,82 ha, tornando-se a segunda categoria em abrangência na bacia e gerando, como consequência, a ampliação dos processos erosivos e de assoreamento, na cabeceira do córrego e no seu trecho de planície, respectivamente. Esses resultados são decorrentes da ocupação pela área urbana da cabeceira da MCAV, com altas taxas de impermeabilização do solo e com falta de manejo das águas pluviais, aumentando consideravelmente o volume de água que chega concentrado no fundo de vale em períodos de chuvas intensas e prolongadas (PIROLI, 2014).

A figura 3 apresenta a distribuição dos usos da terra em 2004, mostrando que as vertentes sul, sudeste e leste foram ocupadas pela área urbana, e as vertentes noroeste e oeste tiveram como ocupação predominante as culturas agrícolas anuais, sobretudo com soja e milho. Em 2004 também foi observada maior dimensão na voçoroca à montante da nascente do córrego Água da Veada, alcançando 3,33 ha. Na categoria culturas agrícolas, foram inseridas diversas plantações de espécies anuais, como feijão e mandioca. Além destas, verificou-se a presença de soja e de milho, que foram identificadas em categorias separadas devido a sua importância em termos de áreas abrangidas.

Figura 3. Mapa de uso da terra na MCAV em 2004.

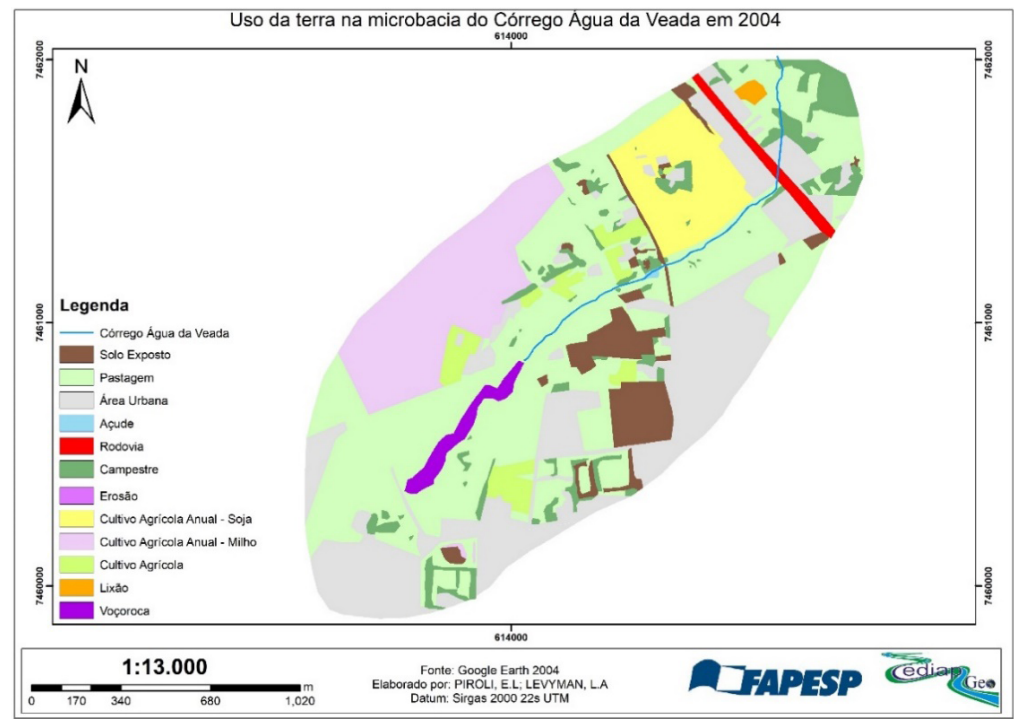




\section{Uso da terra na MCAV, Ourinhos-SP, 2016}

Em 2016 destaca-se a pastagem, que cobria $35,77 \%$ da área, seguida de perto pela área urbana, que abrangia $32,50 \%$. Além destas, o eucalipto e as culturas agrícolas cobriam importantes percentuais da área, 12,51\% e 6,83\%, respectivamente. Observa-se ainda que o lixão mudou de lugar, indo para perto da voçoroca, resultado de uma tentativa de recuperação da área com depósito de entulhos. A figura 4 mostra o uso da terra em 2016.

Figura 4. Uso da terra na MCAV em 2016.

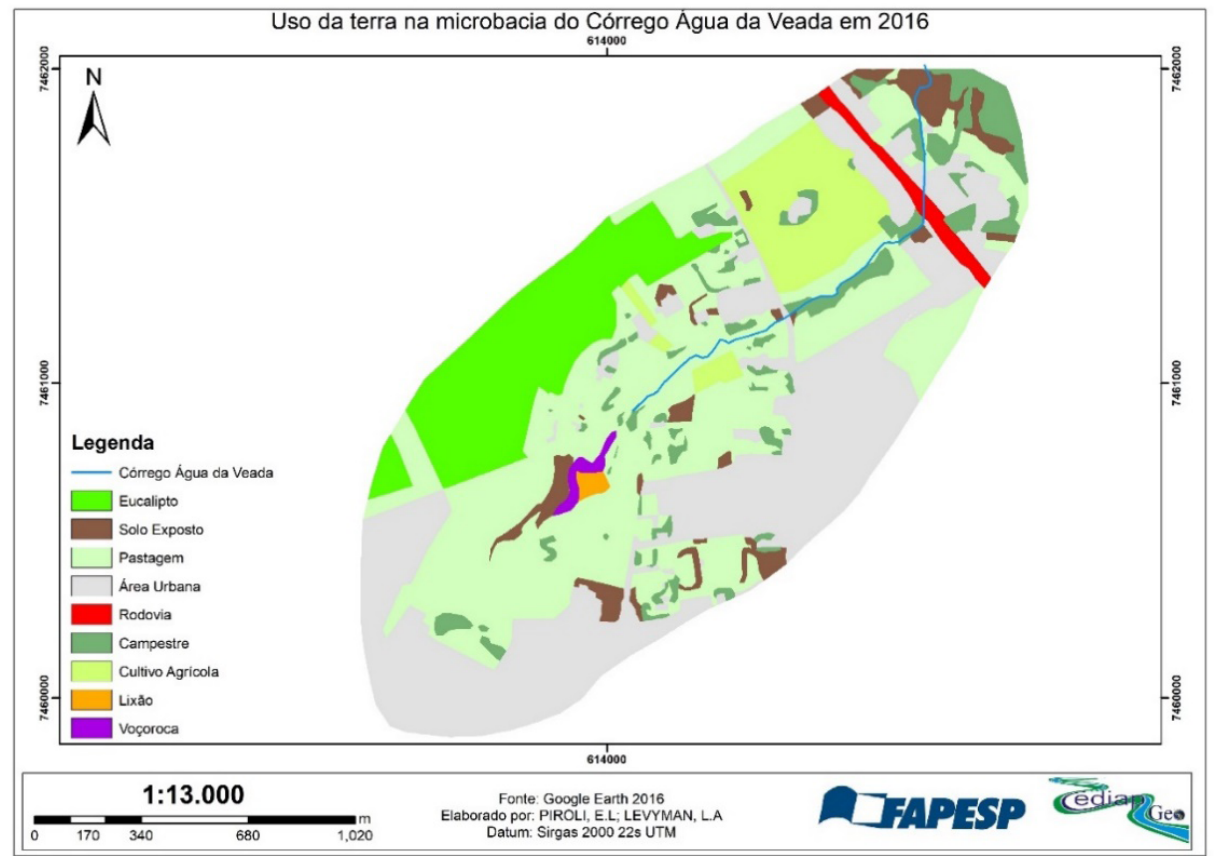

Figura 5. Mudanças nas áreas cobertas por cada uso da terra em cada ano estudado.

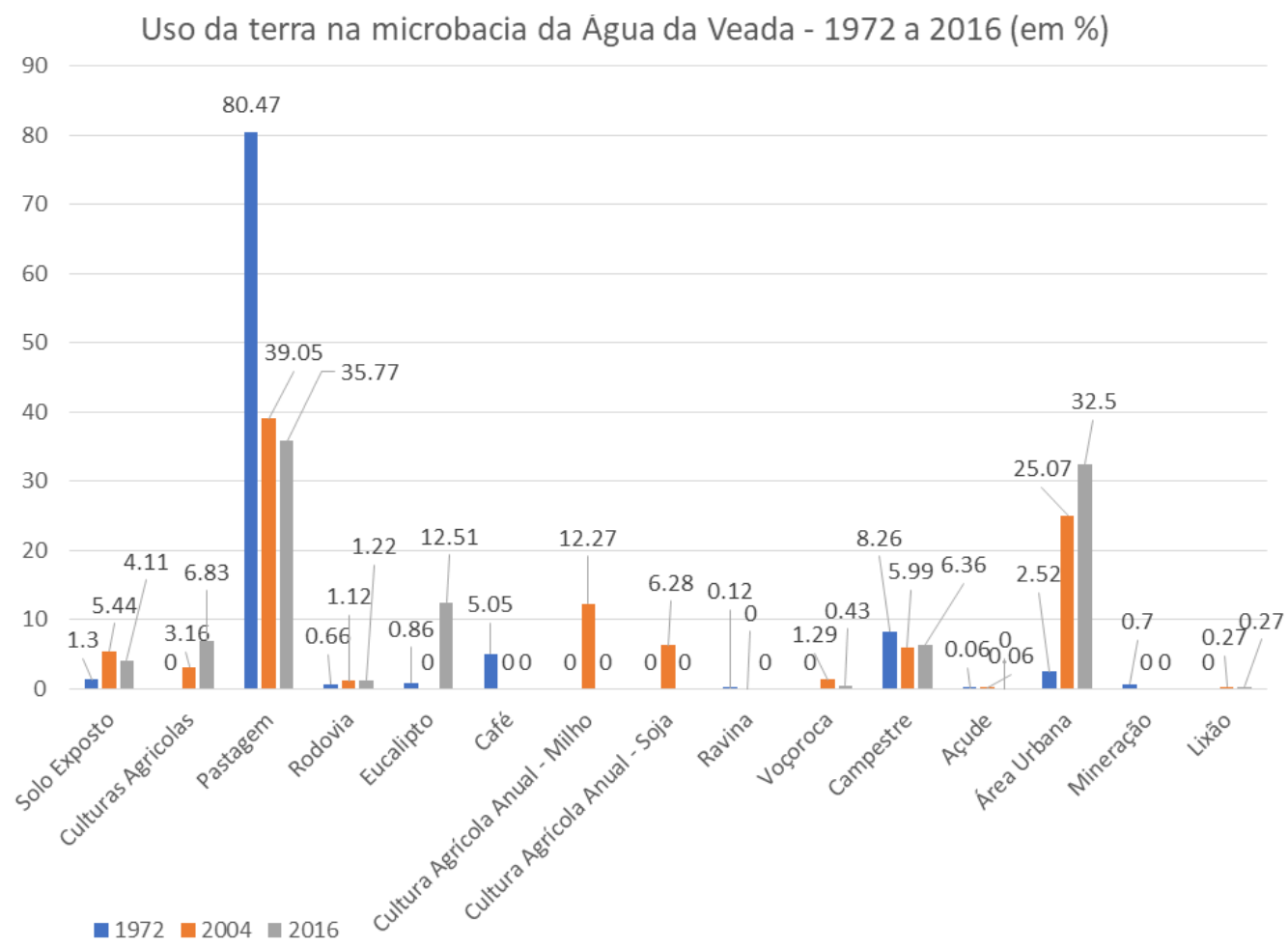


Visando sintetizar os dados do uso da terra nos anos avaliados, a figura 5 demonstra as mudanças nas porcentagens de cada uso da terra ocorrido entre 1972 e 2016. Nela, destacam-se a redução das áreas de pastagens, o aumento das áreas urbanas, a exclusão do café, a manutenção das áreas com cobertura campestre e as trocas entre as culturas agrícolas.

A tabela 1 sintetiza a área de cada uso da terra e sua porcentagem em cada ano estudado.

Tabela 1. Abrangência das coberturas da terra na MCAV nos três anos analisados, com áreas e porcentagens.

\begin{tabular}{|c|c|c|c|c|c|c|c|}
\hline \multicolumn{8}{|c|}{ Água da Veada - Uso da terra em hectares (ha) e porcentagem } \\
\hline Id. & Uso & 1972 & $\%$ & 2004 & $\%$ & 2016 & $\%$ \\
\hline 1 & Solo Exposto & 3,37 & 1,30 & 14,07 & 5,44 & 10,62 & 4,11 \\
\hline 2 & Culturas Agrícolas & 0 & 0 & 8,17 & 3,16 & 17,67 & 6,83 \\
\hline 3 & Pastagem & 208,08 & 80,47 & 100,98 & 39,05 & 92,49 & 35,8 \\
\hline 4 & Rodovia & 1,7 & 0,66 & 2,9 & 1,12 & 3,15 & 1,22 \\
\hline 5 & Eucalipto & 2,23 & 0,86 & 0 & 0 & 32,35 & 12,5 \\
\hline 6 & Café & 13,06 & 5,05 & 0 & 0 & 0 & 0 \\
\hline 7 & Campestre & 21,36 & 8,26 & 15,49 & 5,99 & 16,44 & 6,36 \\
\hline 8 & Cultura Agrícola Anual - Milho & 0 & 0 & 31,72 & 12,27 & 0 & 0 \\
\hline 9 & Cultura Agrícola Anual - Soja & 0 & 0 & 16,23 & 6,28 & 0 & 0 \\
\hline 10 & Ravina & 0,3 & 0,12 & 0 & 0 & 0 & 0 \\
\hline 11 & Voçoroca & 0 & 0 & 3,33 & 1,29 & 1,12 & 0,43 \\
\hline 12 & Açude & 0,16 & 0,06 & 0,16 & 0,06 & 0 & 0 \\
\hline 13 & Área Urbana & 6,52 & 2,52 & 64,82 & 25,07 & 84,05 & 32,5 \\
\hline 14 & Mineração & 1,8 & 0,70 & 0 & 0 & 0 & 0 \\
\hline 15 & Lixão & 0 & 0 & 0,71 & 0,27 & 0,69 & 0,27 \\
\hline Total & & 258,58 & 100 & 258,58 & 100 & 258,58 & 100 \\
\hline
\end{tabular}

(0) não identificado no ano.

\section{Mudanças no uso da terra na MCAV, Ourinhos-SP, entre 1972 e 2004}

Entre 1972 e 2004 ocorreu importante perda na categoria pastagem, que foi reduzida de 208,08 para 100,98 ha. Nesse período a área urbana se ampliou de 6,52 para 64,82 ha, principal fator para o aumento do escoamento superficial e que gerou a ampliação da voçoroca na microbacia, conforme pode ser observado na fotografia (figura 6), em que são visíveis o lençol freático e seu processo de assoreamento.

Figura 6. Aspecto do processo erosivo e exposição do lençol freático.

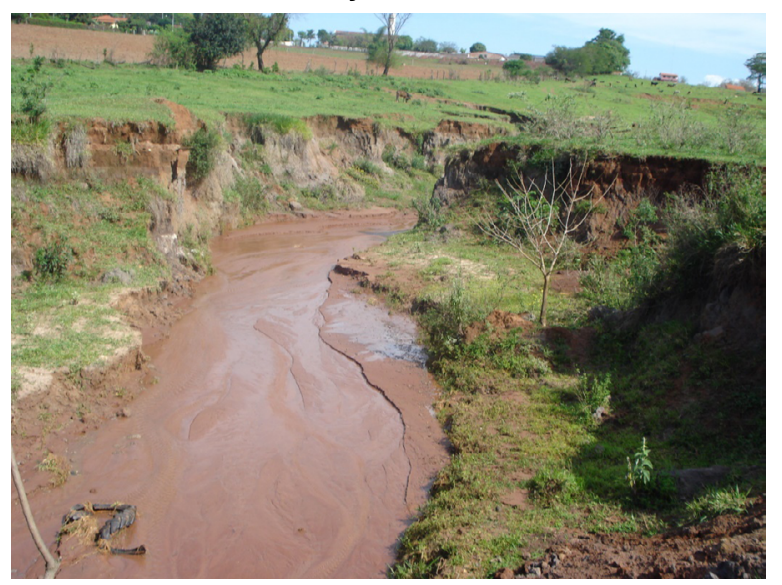

A figura 7 mostra as perdas, persistências e ganhos nas principais categorias de uso da terra entre 1972 e 2004. Na letra A é mostrada a área onde existia café plantado em 1972 e, em 2004, pode-se ver que a plantação havia sido substituída principalmente pela área urbana. Como o grão estava plantado na região alta da cabeceira da MCAV, na zona de infiltração (SOUZA; FERNANDES, 2000), ao ser substituído por estruturas urbanas, o local passou a ser uma zona de escoamento. Como isso aconteceu com todos os usos localizados na região, tem-se a explicação para os processos erosivos surgidos no período. Com relação à categoria campestre (mapa B), observou-se que foi substituída principalmente pela área urbana e pela pastagem na vertente sul da microbacia. Por sua vez, a foz foi ampliada, provavelmente devido à proximidade com o rio Pardo e à pressão da legislação ambiental.

A pastagem (letra C) continuou cobrindo a maior parte da microbacia, ganhando pequenos espaços na porção sul e perdendo áreas no lado leste, sobretudo na região do divisor de águas e na vertente, locais onde a água deveria se infiltrar, o que, porém, tem deixado de ocorrer em razão das altas taxas de impermeabilização aplicadas na área. Já as áreas urbanas, representadas no mapa da letra $\mathrm{D}$, se ampliaram consideravelmente, ocupando principalmente os espaços anteriormente usados para atividades agropecuárias. 
Figura 7. Mapas mostrando as perdas, persistências e ganhos das classes café (A), campestre (B), pastagem (C) e área urbana (D) entre 1972 e 2004.
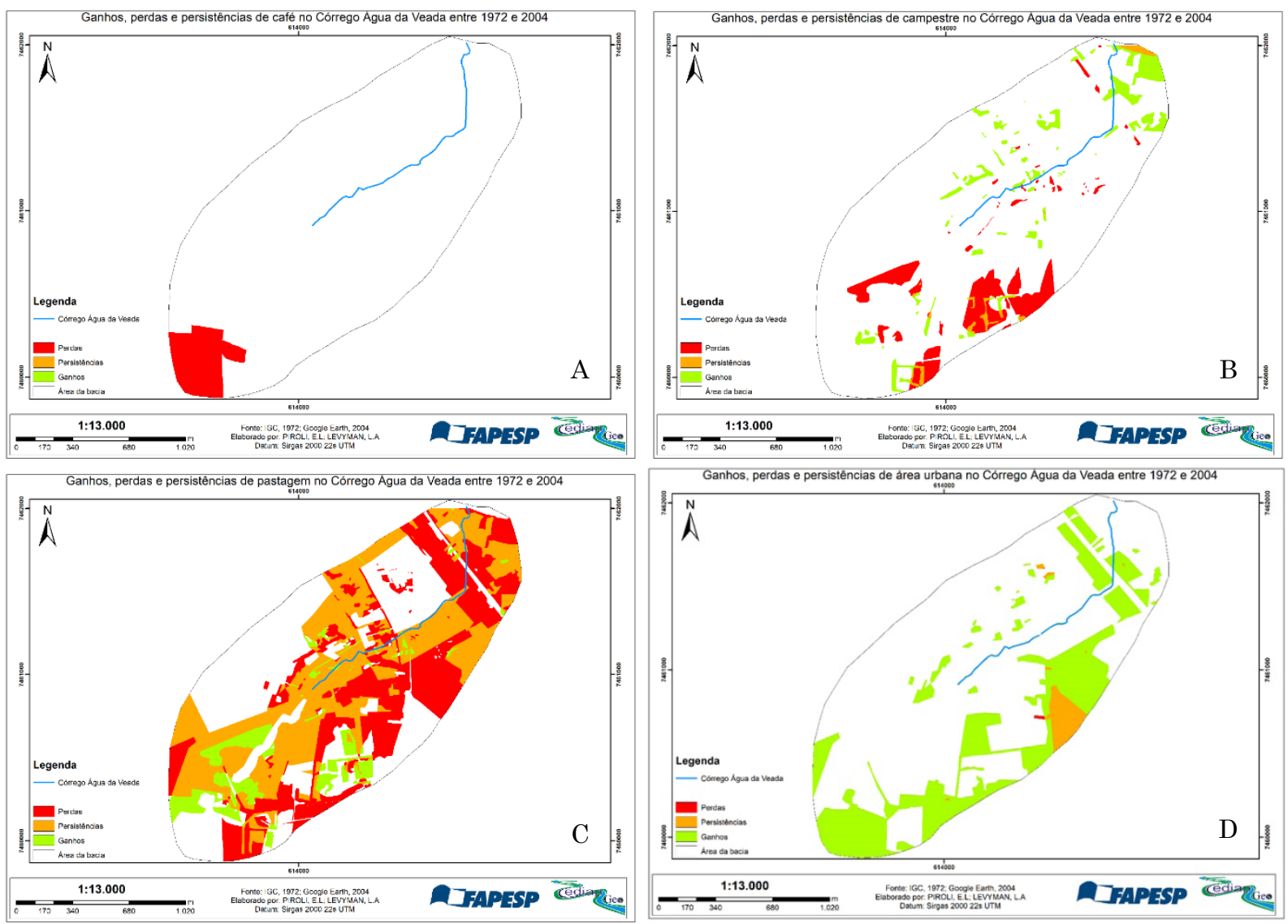

\section{Mudanças no uso da terra na MCAV, Ourinhos-SP, entre 2004 e 2016}

Entre 2004 e 2016 as principais mudanças ocorridas na área foram relacionadas às perdas da categoria de pastagem e aos ganhos na classe áreas urbanas. Esta última se consolidou na maior parte da vertente leste da MCAV, ampliando ainda mais as áreas impermeabilizadas e potencializando escoamentos superficiais, erosões e assoreamentos.

A figura 8 apresenta, na letra $\mathrm{A}$, as perdas, persistências e ganhos da categoria campestre. Nela é possível observar que essa dinâmica é mais intensa em uma faixa central, que vai do sul ao norte da microbacia

hidrográfica, desde a cabeceira até a foz. A pastagem (letra B) se manteve em áreas ainda consideráveis e perdeu espaço em outras, com ganhos dispersos pela área. Essas trocas se devem principalmente à rotação de culturas com cultivos anuais, comuns na área, nas porções rurais.

A letra C mostra os avanços da área urbana sobre a microbacia, indicando que esta continua se expandindo, ampliando as áreas impermeabilizadas. Na letra D são apresentadas as trocas ocorridas com a categoria cultivos agrícolas, classe que apresenta dinâmica bastante rápida, pois está relacionada às culturas de ciclo curto e às demandas locais, nacionais e internacionais por produtos como soja e milho. 
Figura 8. Ganhos, perdas e persistências nas classes de uso campestre (A), pastagem (B), área urbana (C) e cultivos agrícolas (D).

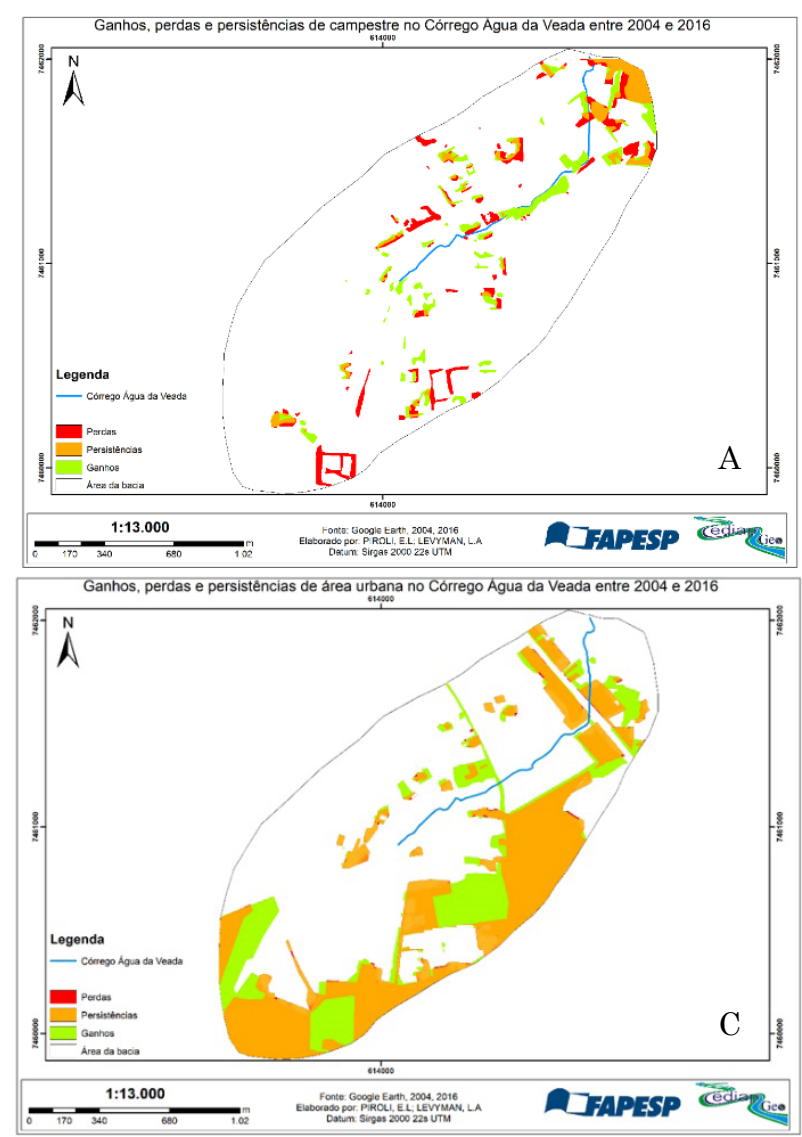

A fim de analisar onde ocorreram as mudanças em cada categoria entre os anos estudados, foram elaborados mapas indicando as trocas de cada classe com as demais. A figura 9 mostra as trocas ocorridas nas categorias
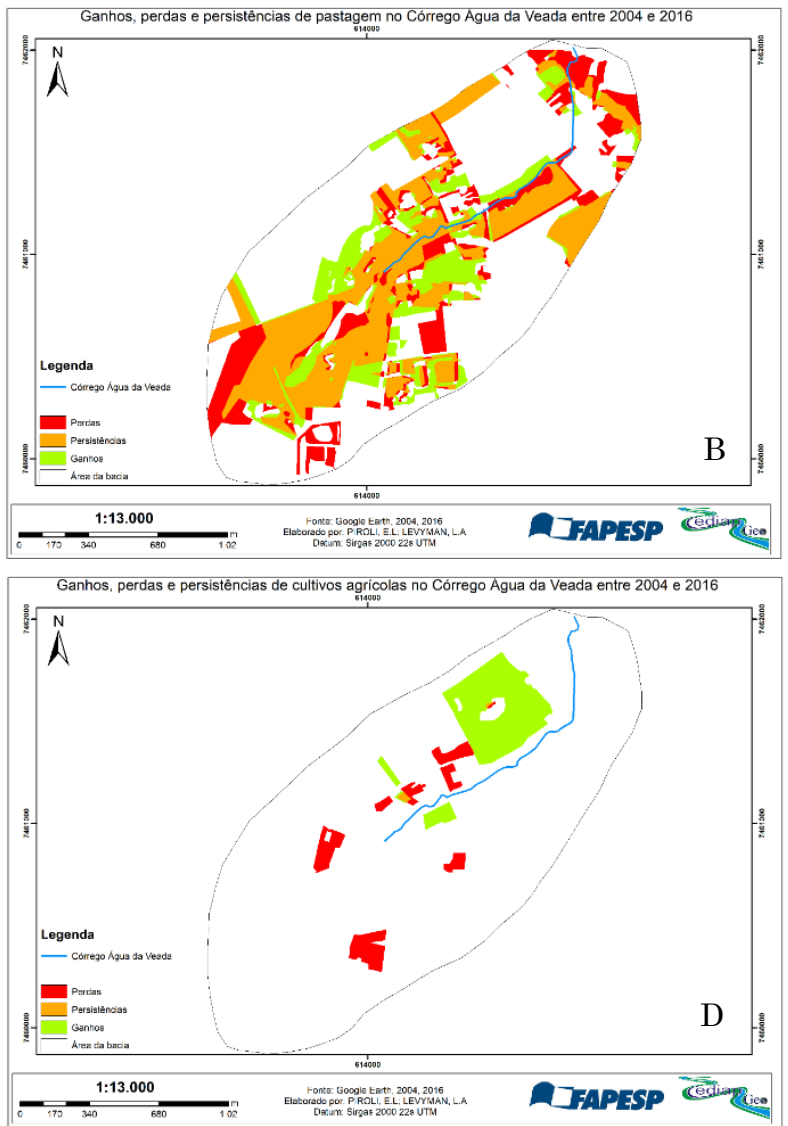

campestre (A) e pastagem (B). Nela é possível observar, com destaque, a substituição dessas categorias pela área urbana. Também é notável a troca da pastagem pela voçoroca e pelo lixão no centro sul da microbacia.

Figura 9. Trocas de uso entre a categoria campestre (A) e as demais coberturas e a categoria pastagem e outros usos (B).
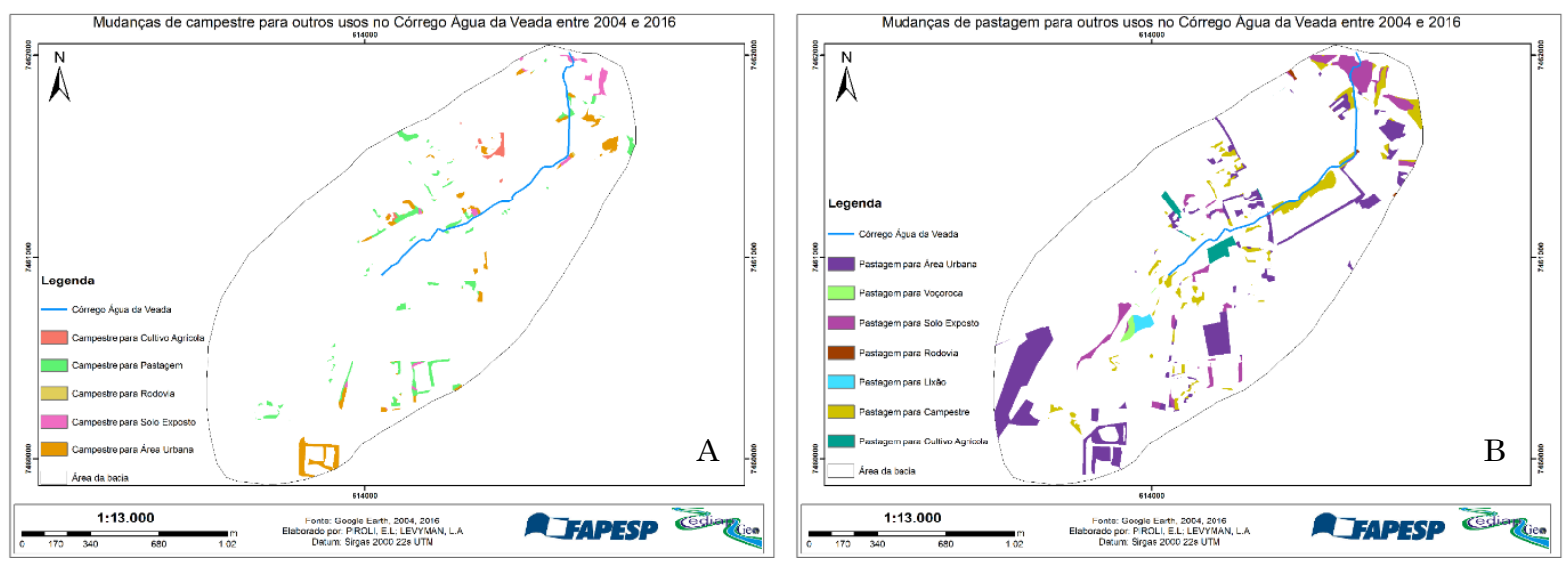
Com relação às áreas de preservação permanente (APP) da nascente e do córrego Água da Veada, houve poucos avanços em termos de proteção com mata ciliar, conforme estabelecido pela legislação brasileira. Em nenhum dos períodos foi observada a categoria floresta, uma vez que, para ser assim determinada, deveria haver algumas características como estrato arbóreo, estrutura fitossociológica definida, camada de liteira presente e variedade de espécies características da fitofisionomia regional (Dadashpoor; Azizi; Moghadasi, 2019). No entanto, visto que a categoria campestre pode se tornar uma floresta se for gerida de maneira adequada e considerando seus melhores resultados em termos de proteção do solo e da água em relação às demais coberturas, nesta análise ela foi a única avaliada como categoria mais adequada para a ocupação da APP.

Em 1972 observa-se que o curso d'água em quase sua totalidade, excluídas sua foz e nascente, estava completamente desprovido de vegetação natural arbustiva ou arbórea. Na época, o Código Florestal, Lei 4.771/1965, definia que a APP deveria ser de 5 metros ao longo dos córregos de até 10 metros de largura, caso do córrego Água da Veada. Visando a comparação com os anos seguintes, adotou-se neste estudo a largura de 30 metros de cada lado dos córregos, conforme estabelecido pela Lei 7.803/1989 e mantido pela Lei 12.651/2012. A figura 10 mostra a distribuição das áreas campestres na MCAV em 1972 e o destaque para a APP.

Figura 10. APP do córrego Água da Veada em 1972.

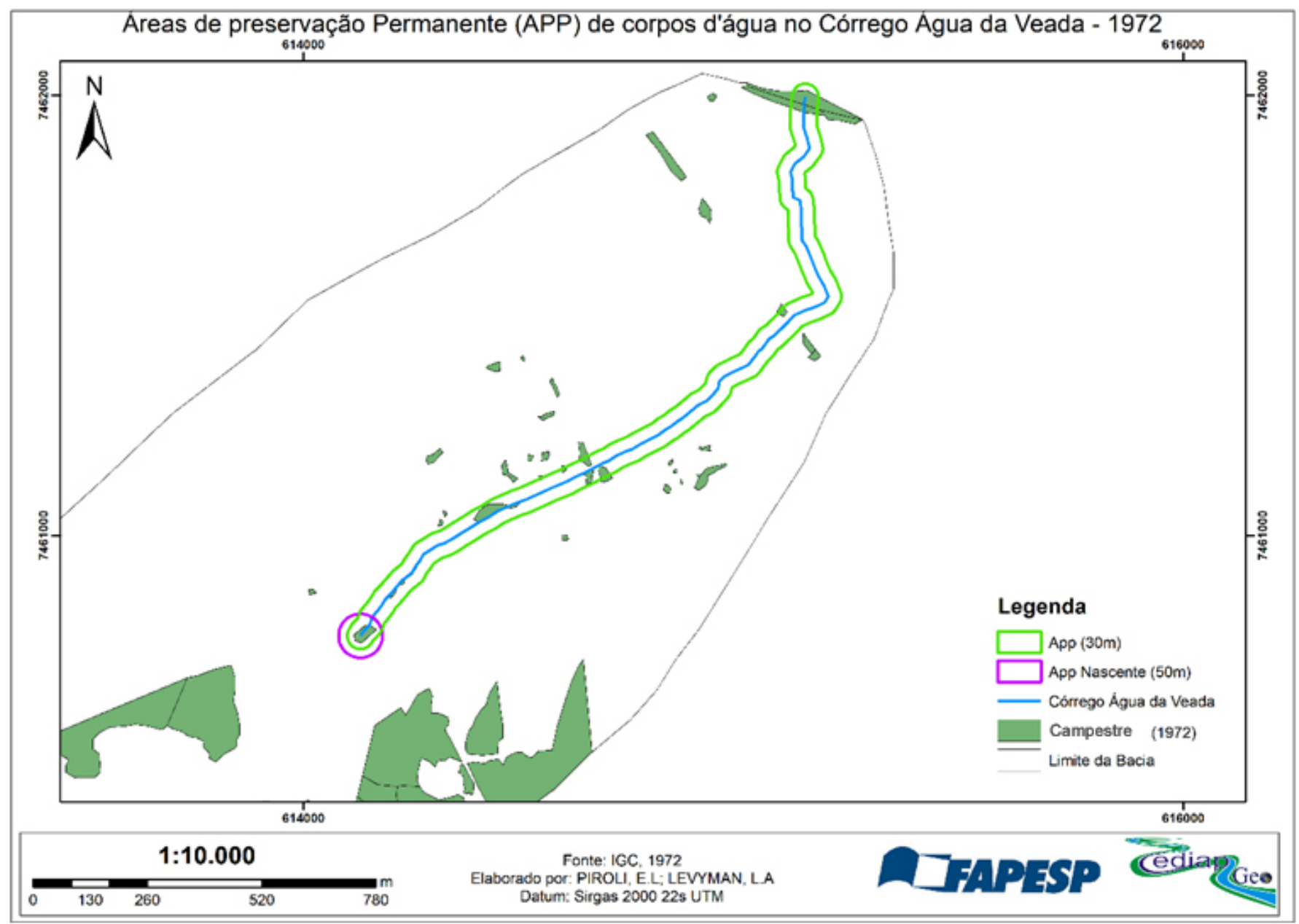

No ano de 2004 é possível observar um espalhamento da categoria campestre ao longo da MCAV, ocupando alguns espaços da APP de maneira aleatória, sem indicar que essa inserção tenha sido feita de maneira planejada para a proteção das águas. A figura 11 (A) mostra a distribuição desse uso na área da $\mathrm{MBH}$. 
Figura 11. Distribuição da categoria campestre nas APP da MCAV em 2004 (A) e em 2016 (B).

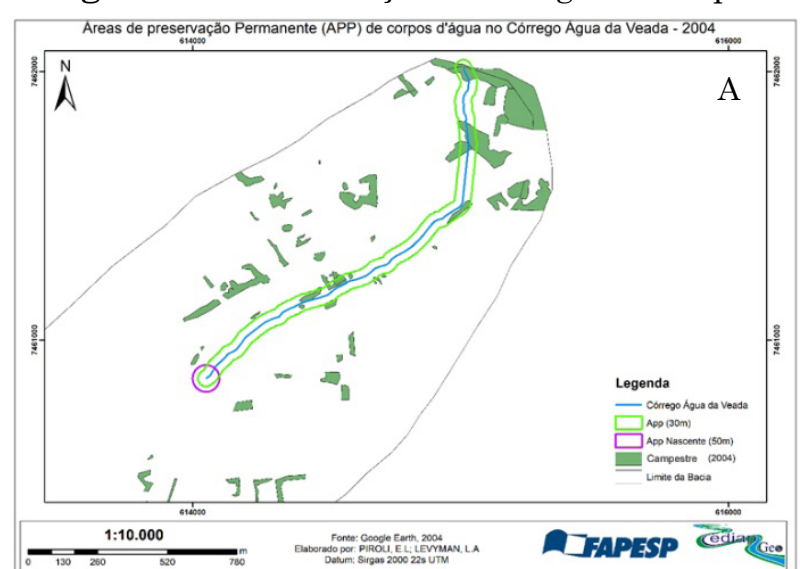

No ano de 2016 houve uma ampliação da categoria, principalmente no trecho médio da APP do córrego e na região próxima à foz, que ocorre no rio Pardo e que tem uma APP de 100 metros no local. Isso pode ser visto na figura 11 (B).

Destaca-se na MCAV o surgimento de uma importante voçoroca entre os dois primeiros períodos analisados (1972 e 2004). Posteriormente, ela variou de tamanho durante os dois últimos períodos avaliados (2004 e 2016). Isso ocorreu devido a tentativas feitas pela prefeitura de canalizar as águas para um ponto diferente do existente em 2004 a jusante da voçoroca. A primeira tentativa ocorreu em 2009, com a implantação de tubos para desvio das águas, e a segunda, em 2014, com o preenchimento

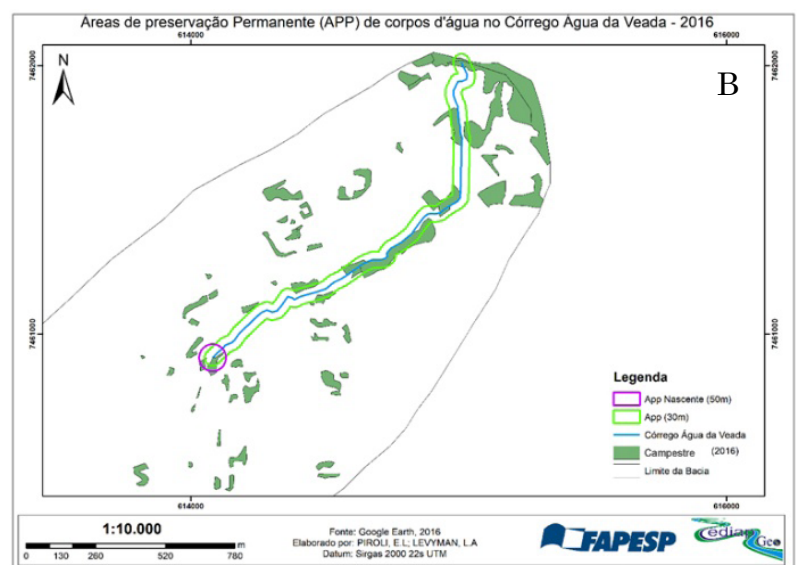

da voçoroca com entulhos das mais diversas origens. Esse processo foi suspenso no mesmo ano por ação do Ministério Público Federal.

A figura 12 mostra a sequência da primeira tentativa de recuperação da área feita em 2009: na letra A é mostrada a placa com os custos da obra em fotografia registrada no dia 13 de setembro de 2009; na letra B, apresenta-se uma retroescavadeira movimentando o solo para a colocação dos tubos, no dia 10 de dezembro de 2009; na letra C se vê o resultado da obra; e, na letra $D$, nota-se a consequência da falta de planejamento e de dimensionamento adequado da obra em ponto da canalização localizado a jusante, no trecho final da obra. Ambas as fotografias foram registradas no dia 16 de março de 2010.

Figura 12. Etapas da tentativa de recuperação da voçoroca" ou algo do gênero.
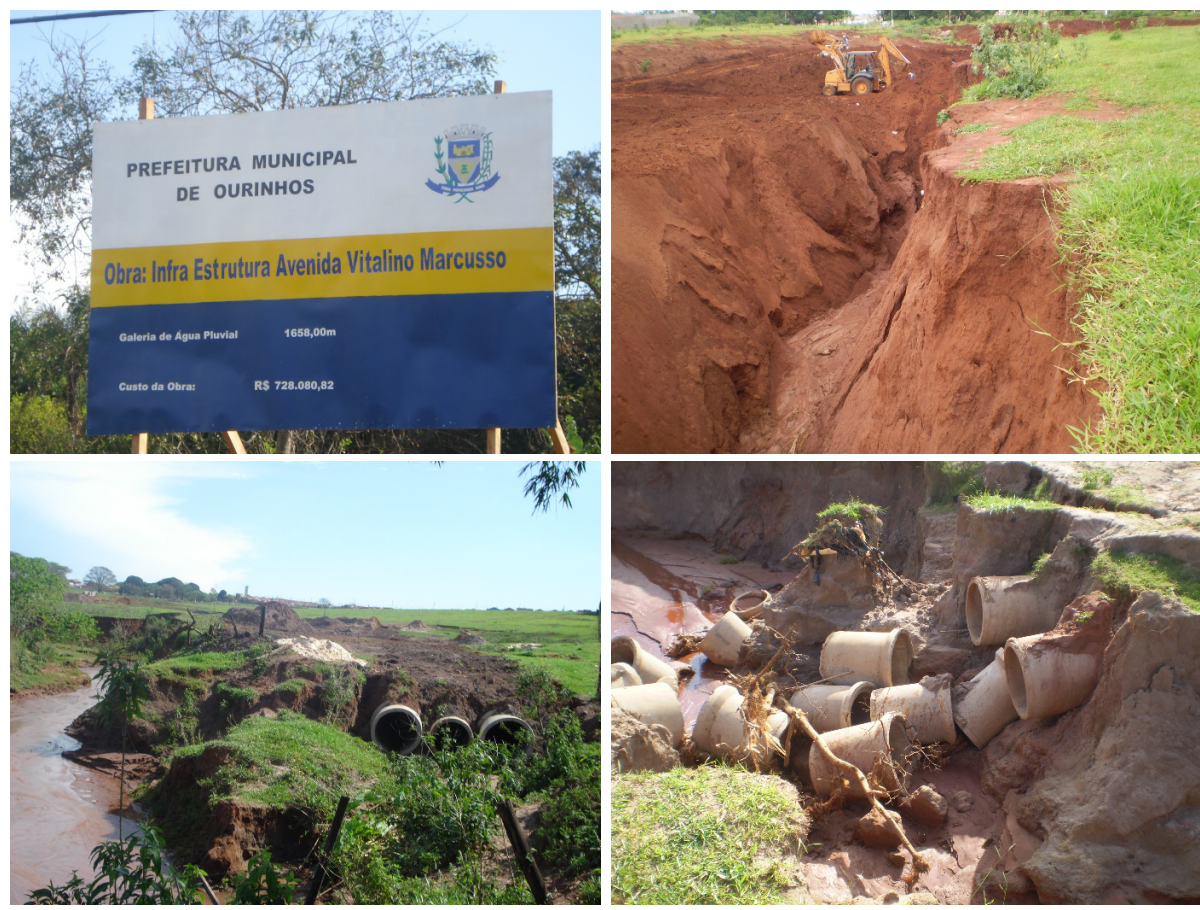
No caso da voçoroca, toda a sequência de tentativas comprovou que não é no processo erosivo que se deve atuar, mas sim na cabeceira e nas vertentes, onde a água se acumula e concentra para depois chegar com energia excessiva nos pontos mais baixos, impactando o solo e os corpos d'água (PIROLI, 2016; TUCGI, 2007).

Brandão et al. (2012) corroboram essa afirmação ao dizerem que a taxa de infiltração no solo é um dos fatores que mais influenciam o escoamento superficial, que é responsável pelos processos de erosão e inundações. Já Pruski, Brandão e Silva (2010) lembram que, das fases associadas ao ciclo hidrológico, a mais importante para obras de engenharia é o escoamento superficial, que corresponde ao segmento relacionado ao deslocamento da água sobre a superfície do solo.

Todos esses autores destacam a importância da manutenção das taxas de infiltração a partir do manejo adequado e conservacionista do solo e da água para reduzir as erosões, as inundações, os assoreamentos e as perdas de água que vão para longe ao invés de ficarem armazenadas no solo atendendo plantas, animais, lençol freático e, ainda, mantendo o ciclo hidrológico, o que é fundamental para a manutenção da produção agropecuária e para a segurança hídrica das populações.

A figura 13 mostra o destaque de parte do resultado da falta de planejamento, do mau dimensionamento e da execução inadequada da obra. Nela, é possível observar que os tubos implantados estão todos quebrados e o processo erosivo ampliado. Assim, todo o trabalho de escavamento e recobrimento deles foi perdido, ampliando-se o prejuízo ambiental, social e financeiro, com a perda, em pouco tempo, de todo o recurso público investido na obra.
Figura 13. Resultado da tentativa de desviar as águas das chuvas por tubos. Fotografia registrada em 16 de março de 2010.

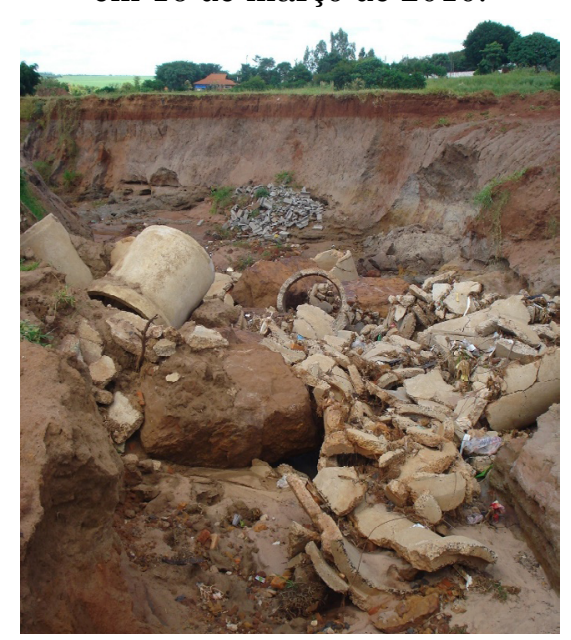

A figura 14 mostra a segunda tentativa feita pela prefeitura de Ourinhos para a solução do problema. Novamente agindo no processo erosivo em vez de atuar no manejo das águas na microbacia, a gestão municipal optou por liberar a deposição de resíduos sólidos das mais diversas origens dentro das erosões. As letras A e B mostram o trânsito intenso de caminhões na área registrado no dia 24 de setembro de 2014, durante uma atividade da Semana da Árvore realizada na Universidade Estadual de Paulista "Júlio de Mesquita Filho" (Unesp), e a quantidade de entulho depositado no local. Na letra C, visualiza-se a diversidade de materiais depositados, que ia desde leivas de grama até móveis usados, passando por restos de construção e de poda de árvores, entre outros. A letra $\mathrm{D}$ destaca a dimensão da voçoroca e o volume de material utilizado para seu preenchimento. 
Figura 14. Fotografias registradas no dia 24 de setembro de 2014 durante atividades da Semana da Árvore 2014, realizada na Unesp.
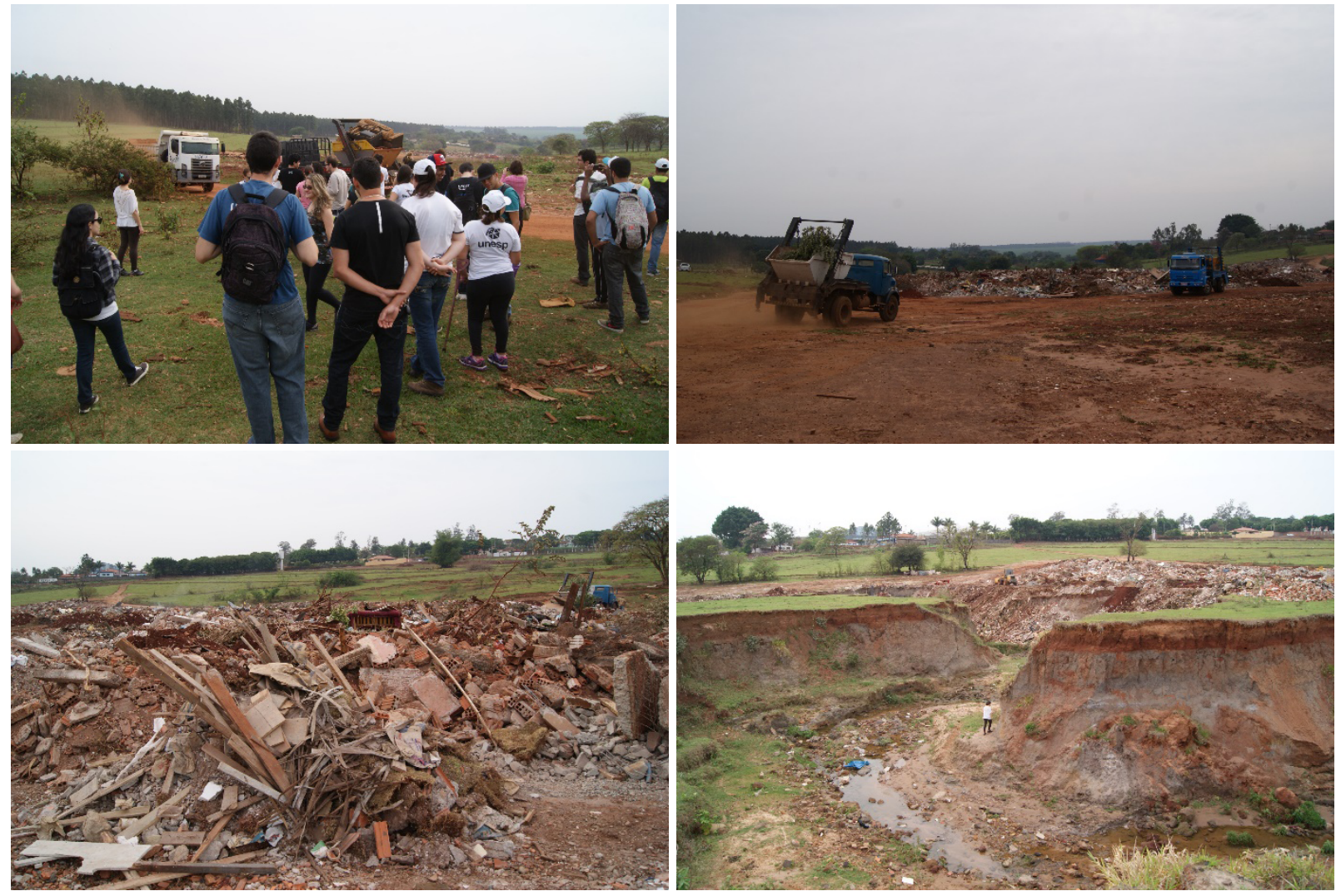

A figura 15 mostra as consequências de uma chuva intensa ocorrida na noite de 25 de setembro de 2014 , um dia após a realização das atividades mostradas na figura 14. Nela, é possível observar o resultado da concentração de água na superfície e as consequências de apenas uma chuva sobre o material inadequado que foi depositado de maneira incorreta no local errado.

A letra A destaca o volume de lixo na superfície, no meio do gramado que era utilizado como pastagem pelo gado bovino criado na área; a letra $\mathrm{B}$ mostra o processo erosivo voltando ao local após uma única chuva; a letra $\mathrm{C}$ apresenta o trecho final da recuperação com entulhos que, após a chuva, voltou à condição de área erodida e agora contaminada; e, na letra D, verifica-se o assoreamento a jusante da voçoroca, onde é possível ver a grande quantidade de material trazido do ponto de deposição. Tal material entupiu o bueiro sob a estrada causando inundação, solapamento de barrancos, consequente queda de parte da estrada e impedimento de uso por um período considerável. A prefeitura precisou refazer parte da estrada e, com isso, gastou ainda mais recursos públicos em obras relacionadas ao processo erosivo que surgiu por falta de planejamento, gestão e manejo da água e do solo na microbacia. 
Piroli, E. L. \& Levyman, L. A.

Figura 15. Fotografias registradas no dia 26 de setembro de 2014 após chuva intensa ocorrida na noite do dia 25 do mesmo mês.
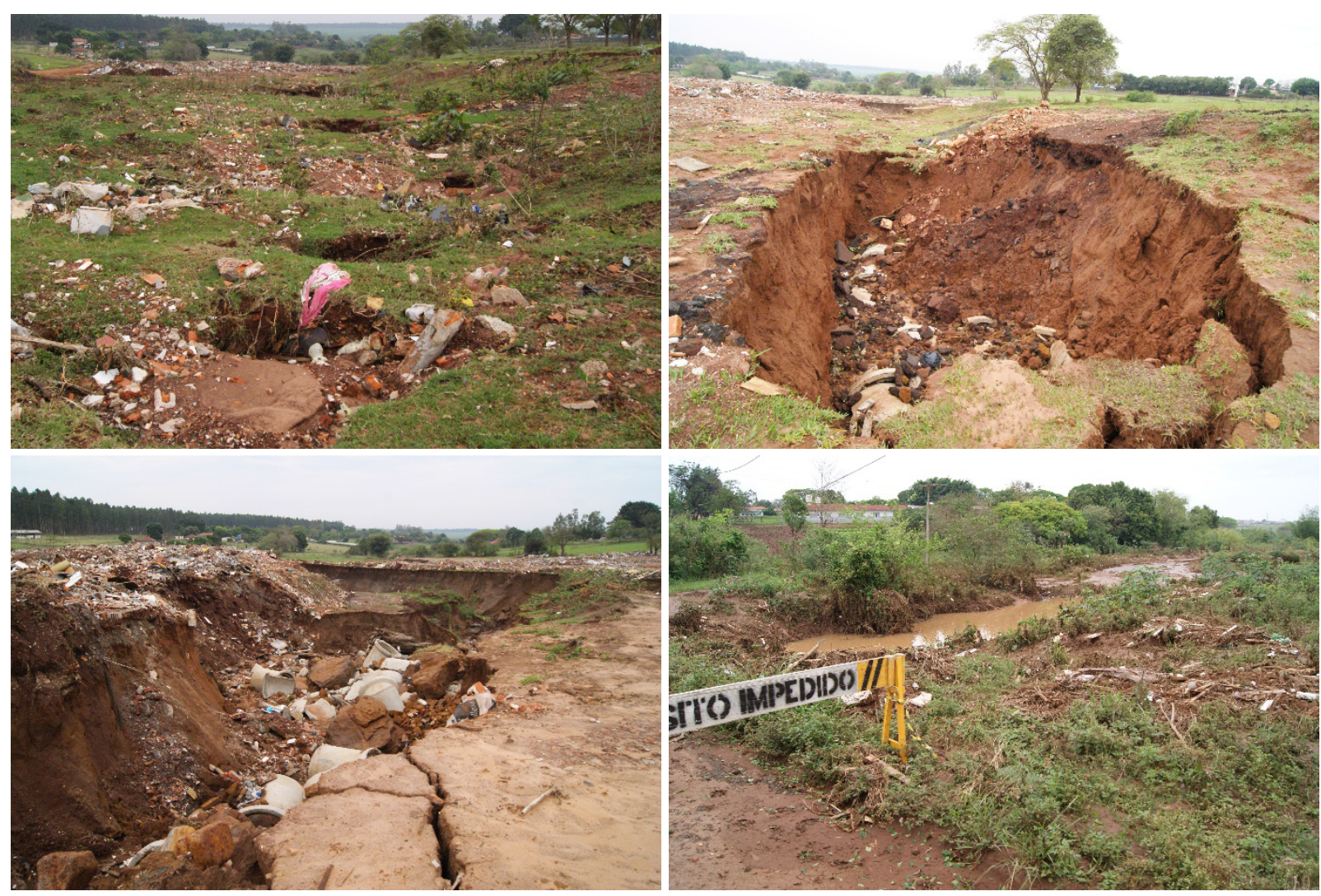

Nunes (2015) afirma que a expansão dos centros urbanos é determinada pela demanda de áreas e por restrições políticas que direcionam o uso da terra, muitas vezes em direção a ambientes frágeis, como florestas, encostas e mananciais. Neste caso, a ocupação com bairros ocorreu em áreas de relevo suave, plano e alto No entanto, por não ter sido feito um planejamento adequado do direcionamento das águas pluviais, por não ter sido implantado um sistema de drenagem racional e por não se considerar as características da microbacia no planejamento da ocupação do espaço, foi criada situação de concentração de águas superficialmente e de escoamento acumulado em direção a um único ponto (figura 16). Esse único ponto passou a receber milhares de litros de água em curtos espaços de tempo (sobretudo em chuvas mais intensas) e não teve proteção do solo e nem de dissipação de energia corretamente implantadas, passando a ser a origem de todo processo de erosão do solo e de assoreamento do córrego. Além disso, posteriormente, a área erodida passou a ser fonte de contaminação do solo e das águas quando se tentou recuperar a área com resíduos sólidos das mais diversas origens.

A figura 16 mostra o ponto onde as águas são concentradas a montante do processo erosivo. Na letra A observa-se a grelha da boca de lobo da avenida Vitalina Marcusso entupida com detritos trazidos pela enxurrada, e a letra $\mathrm{B}$ apresenta os tubos por onde a água é direcionada para a pastagem onde surgiu a voçoroca. Destaca-se que o entupimento da boca de lobo não modifica em nada a concentração e o aporte de água em um único ponto, sem proteção do solo e sem sistema de dissipação de energia adequadamente dimensionado, uma vez que, se a água entra pelos bueiros ou se escoa por cima destes, o resultado será o mesmo em termos de volume e energia, causando e ampliando as erosões. A água que chega até esse ponto é coletada em toda cabeceira da MCAV ocupada por área urbana com os bairros Jardim Brilhante e Santa Fé.

Esse contexto corrobora Tominaga (2009), que informa que, entre os principais desastres naturais recorrentes no estado de São Paulo estão as erosões aceleradas e as inundações, sendo as primeiras presentes sobretudo nas regiões central e oeste do estado. A autora destaca a importância de estudos e da observação da legislação para reduzir os riscos desse tipo de problema. 
Figura 16. Fotografias obtidas no dia 26 de setembro de 2014 mostrando o ponto de concentração da água.
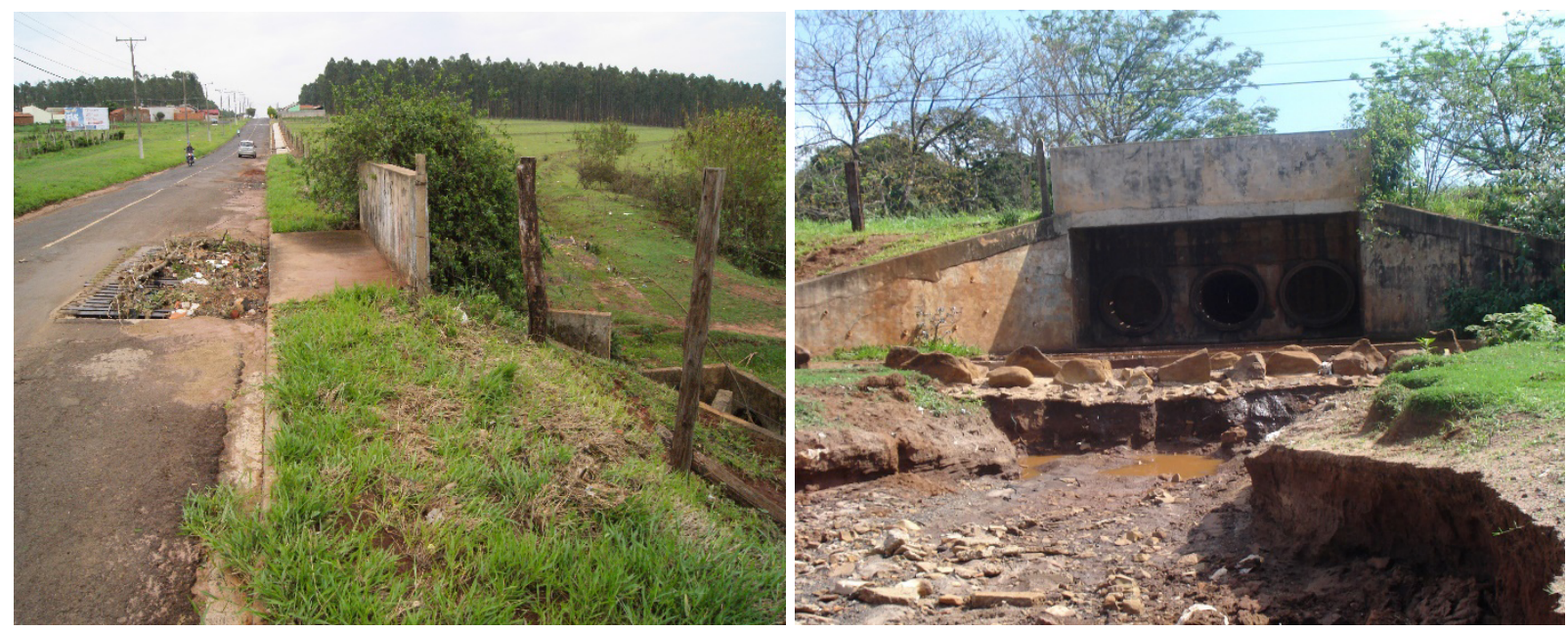

Visto que a questão fundiária em uma microbacia também pode ter impacto nos usos da terra, verificou-se como a situação está atualmente na MCAV. O mapa apresentado na figura 17 mostra a distribuição das propriedades rurais da área de acordo com o Cadastro Ambiental Rural (CAR). Nela, observa-se que as propriedades já

registradas estão localizadas na porção oeste, ocupando pequena porção da microbacia. A maior parte da área já está sob ocupação urbana, o que faz com que não sejam registradas nesse cadastro. Entre aquelas registradas, não foram identificadas reservas legais, o que pode ser considerado uma falha diante da legislação vigente.

Figura 17. Mapa do Cadastro Ambiental Rural.

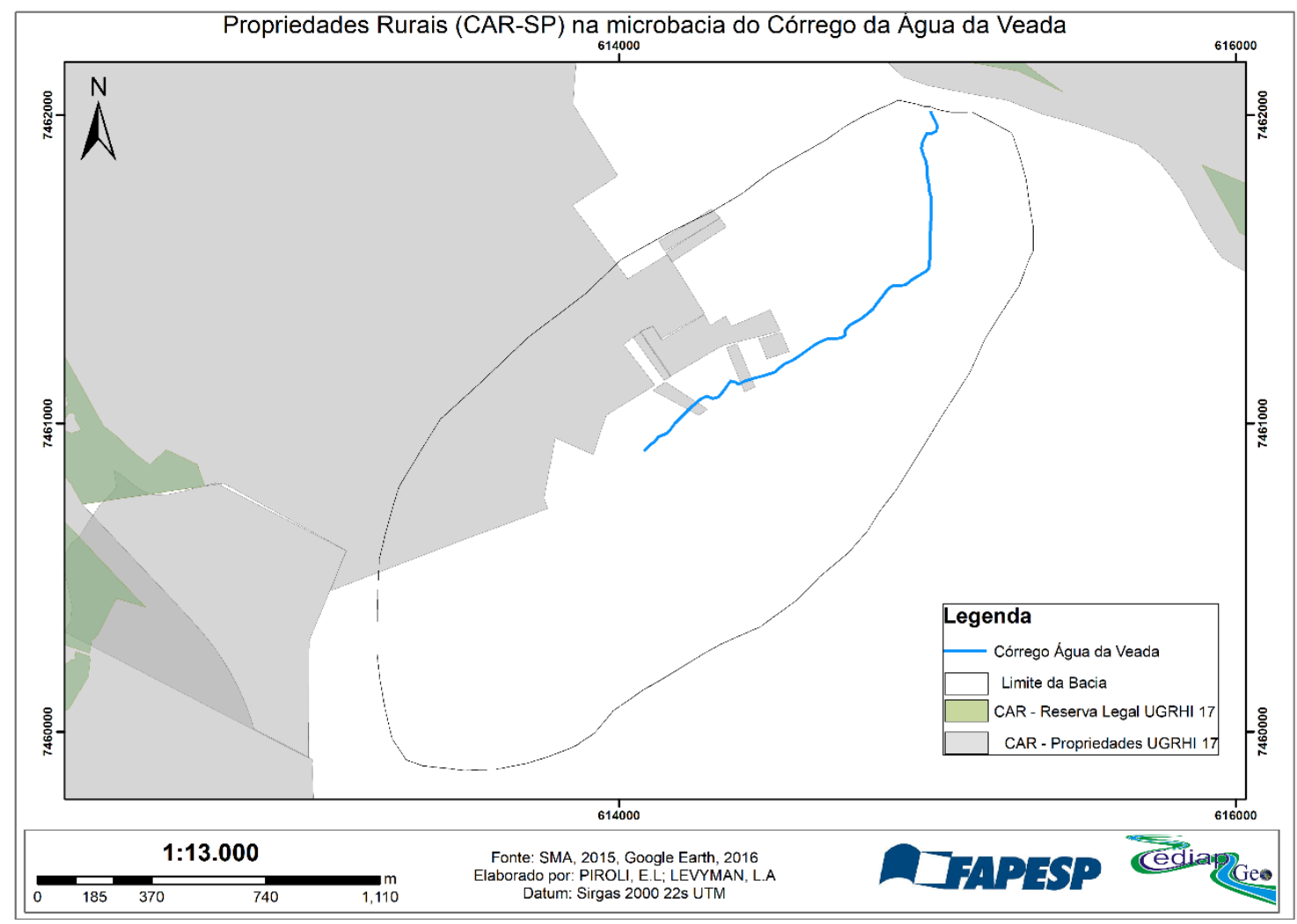


A figura 18 mostra o mapa de classes de declives da área. Nele é possível ver que os maiores declives estão localizados no médio curso do córrego em ambos os lados.
Esse fator colabora para que as águas pluviais concentradas na superfície adquiram velocidade, aumentando sua capacidade erosiva.

Figura 18. Mapa de declives da MCAV.

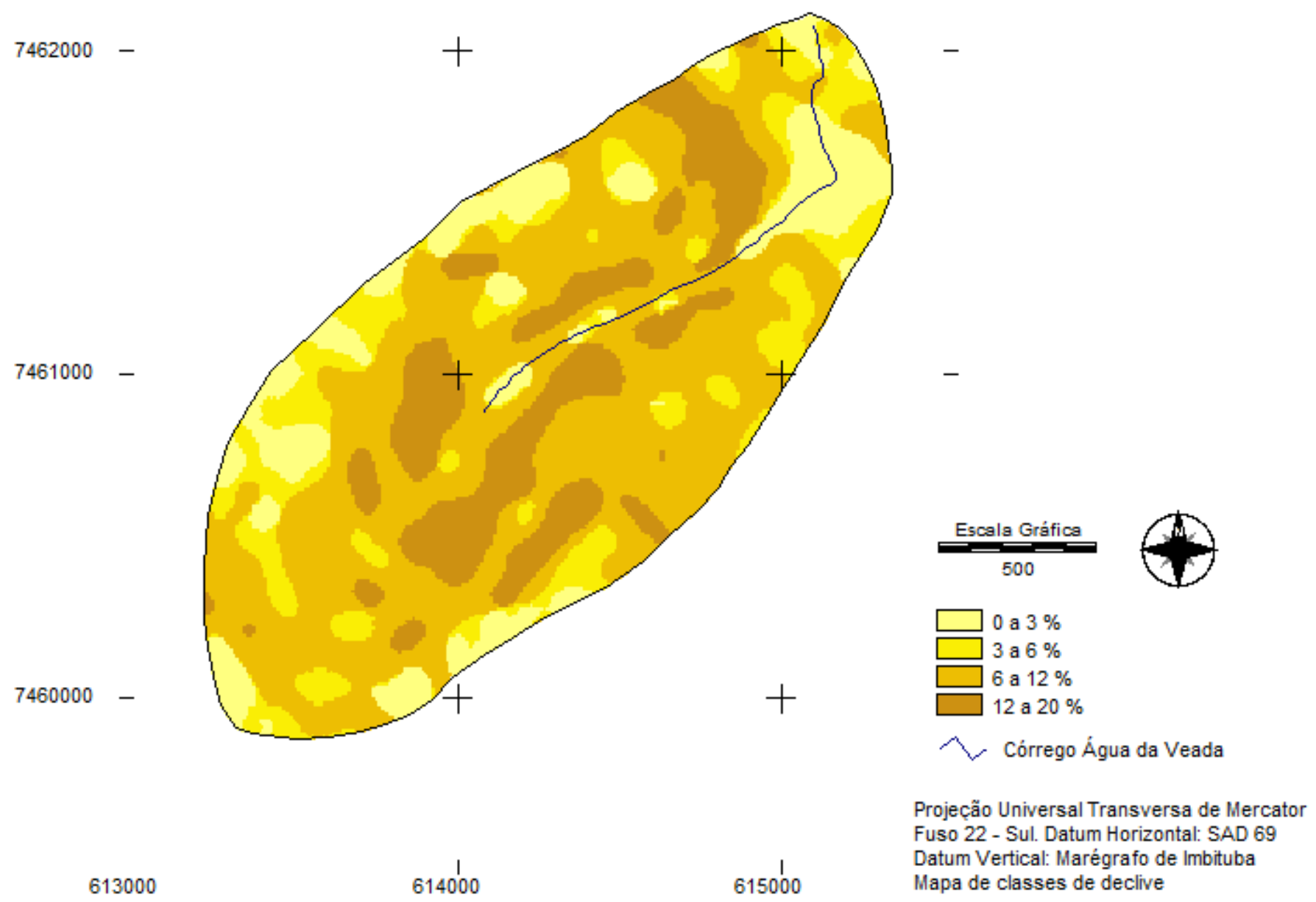

Esse conjunto de figuras demonstra que o crescimento das cidades sem planejamento adequado tem contribuído para importantes impactos sobre o solo e a água. Zanata e Perusi (2010) afirmam que a erosão é um fenômeno natural que ocorre independentemente da ação humana, que, no entanto, tende a intensificá-la. As autoras já demonstravam em 2010 que a origem do processo erosivo que ocorre na área estudada era o ponto de lançamento da água oriunda da rede de drenagem da avenida dentro de uma propriedade privada no perímetro urbano.

Em entrevistas com a população da área, identificouse que os problemas com as águas pluviais superficiais ocorrem também nos pontos mais baixos da área urbana situada na cabeceira da microbacia. Processos de erosão, assoreamento, arraste de lixo e inundações em algumas ruas são comuns, o que pode gerar riscos para a saúde das pessoas, tanto em função das águas contaminadas quanto pelo risco de quedas e acidentes durante as chuvas mais intensas que acumulam suas águas na superfície, consequência das altas taxas de impermeabilização do solo.

\section{CONSIDERAÇÕES FINAIS}

As análises efetuadas neste trabalho demonstram que a MCAV sofreu alterações significativas do uso da terra na maior parte de suas áreas entre 1972 e 2016. As mudanças mais importantes e que têm acarretado consequências graves para o solo e para a os corpos d'água ocorreram na cabeceira da MCAV, com a substituição de usos agropecuários por áreas urbanas.

As infraestruturas urbanas relativas à drenagem das águas pluviais não foram adequadamente planejadas e 
não houve preocupação com as consequências da concentração dessas águas em um único ponto. Verificou-se que os processos erosivos causam impactos significativos nos solos da área, e o assoreamento de seu vale gera prejuízos importantes para o ecossistema do córrego, comprometendo o ambiente e praticamente extinguindo todas as formas de vida ali existentes.

Ao redor da nascente e ao longo do córrego não foram encontradas matas ciliares, o que contribui ainda mais para a falta de estabilidade das margens dos corpos d'água, potencializando erosões e assoreamentos.

Observou-se ainda que os custos financeiros em termos de tentativas de recuperação na área chegaram à casa das centenas de milhares de reais, sem, no entanto, chegar perto de alguma solução definitiva, uma vez que as tentativas de solução dos problemas foram direcionadas a ações pontuais nos locais onde as águas pluviais chegam concentradas, contrariando as recomendações técnicas de ação na bacia de captação com manejo adequado das águas das chuvas.

Notou-se também que a falta de planejamento adequado, somada à inexistência de projetos de drenagem eficientes, trouxe à área e à sua população riscos ampliados em todas as chuvas um pouco mais intensas.

\section{REFERÊNCIAS}

BRANDÃO, V. S. et al. Infiltração da água no solo. 3. ed. Viçosa, MG: Ed. UFV, 2012.

BRASIL. Lei n ${ }^{\circ} 4.771$, de 15 de setembro de 1965. Institui o Novo Código Florestal Brasileiro. Diário Oficial da União, Brasília, DF, 16 set. 1965.

BRASIL. Lei $n^{\circ} 7.803$, de 18 de julho de 1989. Altera a redação da Lei $\mathrm{n}^{\circ} 4.771$, de 15 de setembro de 1965, e revoga as Leis ${ }^{\text {os }_{5}} 6.535$, de 15 de junho de 1978, e 7.511 , de 7 de julho de 1986. Diário Oficial da União, Brasília, DF, 20 jul. 1989.

BRASIL. Lei n ${ }^{\circ} 12.651$, de 25 de maio de 2012. Dispõe sobre a proteção da vegetação nativa; altera as Leis $\mathrm{n}^{\mathrm{o}} \mathrm{s} 6.938$, de 31 de agosto de 1981, 9.393, de 19 de dezembro de 1996, e 11.428, de 22 de dezembro de 2006; revoga as Leis $\mathrm{n}^{\circ} \mathrm{S} 4.771$, de 15 de setembro de 1965, e 7.754, de 14 de abril de 1989, e a Medida Provisória n ${ }^{\circ}$ 2.166-67, de 24 de agosto de 2001; e dá outras providências. Diário

Oficial da União, Brasília, DF, 28 maio 2012.
DADASHPOOR, H.; AZIZI, P.; MOGHADASI, M. Land use change, urbanization, and change in landscape pattern in a metropolitan area. Science of The Total Environment, Amsterdam, v. 655, p. 707-719, 2019.

FLORENZANO, T. G. Iniciação em sensoriamento remoto. 3. ed. São Paulo: Oficina de Textos, 2011.

INSTITUTO BRASILEIRO DE GEOGRAFIA E ESTATÍSTICA. Manual técnico de uso da terra. 3. ed. Rio de Janeiro: IBGE, 2013.

JACOBI, P. R.; CIBIM, J. C.; SOUZA, A. N. Crise da água na Região Metropolitana de São Paulo - 2013/2015. GeoUsp, São Paulo, v. 19, n. 3, p. 422-444, 2016.

JENSEN, J. R. Sensoriamento remoto do ambiente: uma perspectiva em recursos terrestres. São José dos Campos: Parêntese, 2009.

KALNAY, E.; CAI, M. Impact of urbanization and land-use change on climate. Nature, London, v. 423, n. 29. p. 528-531, 2003.

Lawler, J. J. et al. Projected land-use change impacts on ecosystem services in the United States. PNAS, Washington, DC, v. 111, n. 20, p. 7492-7497, 2014.

\section{NUNES, L. H. Urbanização e desastres naturais.} São Paulo: Oficina de Textos, 2015.

OROSCO, R. T. Conflitos na gestão de recursos hídricos no Brasil: o caso da interligação JaguariAtibainha na bacia hidrográfica do Rio Paraíba do Sul. In: SIMPÓSIO DE REGURSOS HÍDRICOS DA BACIA DO RIO PARAÍBA DO SUL, 3., 2018, Juiz de Fora. Anais [...]. Juiz de Fora: Universidade Federal de Juiz de Fora, 2018.

PIROLI, E. L. Água: por uma nova relação. Jundiaí: Paco, 2016.

PIROLI, E. L. Geoprocessamento aplicado ao estudo da evolução do uso da terra e seus impactos sobre a infiltração de água em microbacias hidrográficas. In: CONGRESSO BRASILEIRO DE ENGENHARIA AGRÍCOLA, 43., 2014, Campo Grande. Anais [...]. Jaboticabal: Associação Brasileira de Engenharia Agrícola, 2014. 
pivetta, m. Uso do solo e as mudanças climáticas. Pesquisa Fapesp, São Paulo, 6 set. 2019. Disponível em: https://bit.ly/3hPMgan. Acesso em: 17 jul. 2021.

PRUSKI, F. F.; BRANDÃO, V. S.; SILVA, D. D. Escoamento superficial. 2. ed. Viçosa, MG: Ed. UFV, 2010.

\section{SETTI, A. A. et al. Introdução ao gerenciamento}

de recursos hídricos. 2. ed. Brasília, DF: Agência Nacional de Energia Elétrica: Superintendência de Estudos e Informações Hidrológicas, 2000.

SOUZA, E. R.; FERNANDES, M. R. Sub-bacias hidrográficas: unidades básicas para o planejamento e a gestão sustentáveis das atividades rurais. Informe Agropecuário, Belo Horizonte, v. 21, n. 207, p. 15-20, 2000.

TOMINAGA, L. K. Desastres naturais: por que ocorrem? In: TOMINAGA, L. K.; SANTORO, J.; AMARAL, R. (org.). Desastres naturais: conhecer para prevenir. São Paulo: Instituto Geológico, 2009.

TUCGI, G. E. M. Inundações urbanas. Porto Alegre: ABRH: Rhama, 2007.

ZANATA, J. M.; PERUSI, M. C. Solos urbanos: degradação ambiental na forma de processos erosivos. Revista Geografia e Pesquisa, Ourinhos, v. 4, n. 2, p. 107-122, 2010. 